\title{
Kodeks Gertrudy, przypadkowa autobiografia księżnej?
}

Większość pytań o przeszłość, stawianych przez badaczy, ma swoje źródło we współczesności. Zazwyczaj są inspirowane problemami, z jakimi stykają się oni w danym momencie. Nie inaczej jest $z$ badaczami średniowiecza. Jednak mimo wielu już dostępnych metod, nadal w odniesieniu do licznych problemów badawczych powstaje więcej hipotez niż twierdzeń. Przyczyna tego tkwi w braku lub niedoskonałości źródeł.

Wiadomo, że w kwestiach kulturowych i etycznych średniowieczne społeczeństwa europejskie były dość hermetyczne. Kobiety postrzegano zazwyczaj jako ograniczone intelektualnie osoby, właściwie pozbawione jakichkolwiek praw, przeznaczone do życia w klasztorze bądź opiekowania się domem. Niewątpliwie takie poglądy znajdują potwierdzenie w przekazach źródłowych, ale głównie dla kobiet pochodzących z nizin społecznych. Zatem, czy można tak samo interpretować sytuację kobiet o korzeniach arystokratycznych?

W ich otoczeniu chłopcy często otrzymywali podstawowe wykształcenie w ramach zakreślonych przez epokę, edukację zdobywali dzięki domowym nauczycielom lub korzystaniu ze szkół parafialnych i katedralnych. Dziewczynki natomiast chętniej posyłano do klasztorów, będących miejscami edukacji, często na wysokim poziomie. Począwszy od pisania i czytania, przez analizę tekstów wybitnych pisarzy i interpretację Biblii, dzieci chłonęły poprawne, jak na owe czasy, wzorce.

Już od IX w. zauważano w kobietach coś szczególnego, zarówno w dobrym, jak i negatywnym sensie. Poeci chwalili np. piękno, nauczyciele przed nim przestrzegali jako przed czymś zgubnym. Wzorce te, tak jak ludzie, poddawane były jednak nieustannej ewolucji. Wydawałoby się dziwne, gdyby spojrzenie na kobietę również się nie zmieniało. Z czasem kobiety zaczęły odgrywać niemałą rolę w życiu politycznym. Stawały się niejednokrotnie czymś w rodzaju karty przetargowej, dzięki której zawierano sojusze lub wypowiadano wojny. Mimo tego, obszerniejszych przekazów o nich jest mało, szczególnie też tych pisanych przez nie same. 
Jednym z przykładów tego typu źródła jest Kodeks Gertrudy Mieszkówny, którego autorstwo badacze przypisują właśnie tej księżnej. Poruszając problem Gertrudy Mieszkówny i jej Modlitewnika należy wyjaśnić pochodzenie tej postaci, co jest istotne z punktu widzenia późniejszego zrozumienia rozpatrywanego tematu.

Gertruda Mieszkówna urodziła się ok. 1025 r., jako córka polskiego króla Mieszka II Lamberta i Rychezy ${ }^{1}$. O księżnej nie traktują bezpośrednio ani źródła polskie, ani ruskie, a przynajmniej nie pojawia się tam jej imię $e^{2}$ Dane te znane są z przekazów pośrednich ${ }^{3}$.

W związku z problemami politycznymi, w które została uwikłana Rycheza, Gertruda dzieciństwo spędziła na dworze cesarskim. Z uwagi na pochodzenie i korzenie matki (siostrzenica Ottona III, wnuczka cesarzowej Teofano) dziewczynka odebrała staranne wykształcenie w duchu cywilizacji zachodniej, z naleciałościami bizantyńskimi. Kształciła się prawdopodobnie w jednym $z$ nadreńskich opactw, gdzie przełożonymi były siostry Rychezy. Tam studiowała teologię oraz filozofię. Nauczyła się także sztuki pisania i czytania ${ }^{4}$.

W 1043 r. wyszła za mąż za Izjasława, syna księcia kijowskiego Jarosława Mądrego. Prawdopodobnie wówczas otrzymała od matki Psatterz Egberta, później znany jako Modlitewnik Gertrudy. Na dworze kijowskim i w miejscach uposażenia jej męża, księżna prawdopodobnie czuła się dość dobrze, była bowiem otoczona ludźmi wychowanymi w duchu religii chrześcijańskiej. Wówczas urodzili się jej trzej synowie: Mścisław, Światopełk-Michał oraz Jaropełk-Piotr (ten ostatni prawdopodobnie był najukochańszym $\mathrm{z}$ nich).

Po rebelii mieszkańców Kijowa, która miała miejsce 15 września 1068 r. Izjasław i Gertruda uciekli do Polski. Prawdopodobnie wówczas księżna zaczęła spisywać swoje przemyślenia na kartach Modlitewnika. W maju 1069 r. Izjasław wrócił do Kijowa, wykorzystując pomoc panującego w Krakowie bratanka Gertrudy - Bolesława II Śmiałego ${ }^{5}$. Księżna bardzo przeżyła

1 S. Kętrzyński, Gertruda (ok. 1025-1108), w. księżna kijowska, [w:] Polski słownik biograficzny, t. 7, red. W. Konopczyński, Kraków 1949-1958, s. 405-406.

2 Oswald Balzer w swojej Genealogii Piastów oznacza Gertrudę jako postać NN.;

O. Balzer, Genealogia Piastów, Kraków 1895, s. 92-93.

3 J. Strzelczyk, Pióro w wattych dłoniach. O twórczości kobiet $w$ dawnych wiekach. Rozkwit (od Murasaki Shikibu do Małgorzaty Poerte), Warszawa 2009, s. 108.

4 A. Andrzejuk, Gertruda Mieszkówna i jej modlitewnik, Warszawa 2006, s. 22.

5 S. Kętrzyński, Gertruda (ok. 1025-1108)..., s. 406. 
powrót na Ruś, co było spowodowane rzezią buntowników, jakiej dokonał jej najstarszy syn ${ }^{6}$.

W marcu 1073 r. przeciw Izjasławowi wystąpili jego młodsi bracia. Efektem zamieszek była ponowna ucieczka rodziny książęcej ${ }^{7}$. Co więcej, okazało się, że razem z buntownikami działał Bolesław II, który być może „otrzymał (albo zagarnął) część mienia Izjasława"s.

Gertruda i Izjasław udali się na dwór króla niemieckiego Henryka IV. Tam podjęli pierwsze próby odzyskania władzy na Rusi. Do Kijowa wysłano poselstwo, które nie osiągnęło zamierzonych rezultatów. W wyniku bezskutecznych działań Henryka IV, rodzina książęca skierowała swoją uwagę w stronę Saksonii, która pozostawała w stanie wojny z cesarzem rzymskim? Co więcej, oznaczało to prawdopodobnie niechciany udział w ogólnoeuropejskim konflikcie politycznym, którego stronami byli papież Grzegorz VII i król Henryk IV. Przypuszcza się, że Gertruda wysunęła pomysł zwrócenia się o pomoc do papieża, co było równoznaczne z obraniem progregoriańskiej opcji politycznej, czyli tej, do której należeli Saksończycy oraz Bolesław II Śmiały. W roli posła do Rzymu odprawiono najmłodszego syna Gertrudy - Jaropełka-Piotra ${ }^{10}$. Papież wystosował dwa listy, jeden z poparciem dla Izjasława, drugi zaś do Bolesława II, nakazujący udzielenie pomocy temu pierwszemu, zarówno finansowej, jak i zbrojnej oraz zwrócenie zrabowanych dóbr ${ }^{11}$.

15 lipca 1077 r. Izjasław z Gertrudą wrócili do Kijowa jako pełnoprawni władcy Rusi. Rok później książę zginął w bratobójczej walce ${ }^{12}$. Po jego śmierci panowanie we Włodzimierzu i Turowie objął najmłodszy syn Gertrudy Jaropełk-Piotr. Warto nadmienić, że być może zarówno Gertruda, jak i Izjasław przewidywali przejęcie tronu właśnie przez Jaropełka. Ten w $1084 \mathrm{r}$. został wygnany przez synów Rościsława. Wówczas z pomocą przyszedł Wsiewołod, książę zwierzchni, ostatni żyjący syn Jarosława Mądrego i stryj Jaropełka. Wydelegował on Włodzimierza Monomacha, swojego syna, który

6 Mścisław miał przygotować Kijów do wkroczenia oddziałów interwencyjnych Bolesława Śmiałego i Izjasława. Nestor skomentował to następująco: „wyciął winnych innych zaś bez winy potracił”; F. Sielicki, Powieść lat minionych, Wrocław-Warszawa-Kraków 1999, s. 136.

7 J. Strzelczyk, Pióro w wątlych dłoniach..., s. 110.

$8 \quad$ A. Andrzejuk, Gertruda Mieszkówna..., s. 26.

$9 \quad$ J. Strzelczyk, Pióro w wątych dłoniach..., s. 110.

$10 \quad$ Ibidem, s. 111.

11 S. Kętrzyński, Gertruda (ok. 1025-1108)..., s. 406.

12 A. Andrzejuk, Gertruda Mieszkówna..., s. 34. 
przywrócił właściwe panowanie we Włodzimierzu. Według ruskiego latopisu, w 1085 r. Jaropełk „chciał iść na Wsiewołoda, posłuchawszy złych doradców. [...] Dowiedziawszy się o tym, Wsiewołod posłał przeciw niemu syna swojego, Włodzimierza"13. Jaropełk, nie chcąc wdawać się w walkę z Monomachem, uciekł do Polski, pozostawiając matkę i żonę na Rusi, gdzie wkrótce stały się jeńcami Monomacha. Zostały one odesłane do Kijowa i osadzone najprawdopodobniej w którymś z kijowskich klasztorów. W 1086 r. Jaropełk wrócił do Kijowa i w zamian za ukorzenie się przed stryjem odzyskał rodzinę i dzielnicę. 22 czerwca $1086 \mathrm{r}^{14}{ }^{14}$ Jaropełk został zamordowany przez Nieradca, prawdopodobnie z polecenia Rościsławowiczów ${ }^{15}$.

Nie wiadomo, co stało się z Gertrudą po wydarzeniach z 1086 r. Domniemywa się, iż przeszła pod opiekę ostatniego z jej żyjących synów Światopełka-Michała, urzędującego w Nowogrodzie ${ }^{16}$. Ostatnia wzmianka o Gertrudzie pojawia się w Powieści lat minionych Nestora wraz z datą śmierci księżnej - 1108 r.: „Tegoż roku zmarła kniahini, Światopełkowa matka, miesiąca stycznia 4 dnia" ${ }^{17}$.

Kolejnym elementem, ważnym dla zrozumienia poruszanej tematyki, a wymagającym wyjaśnienia i opisania jest Modlitewnik, którego autorstwo przypisuje się Gertrudzie Mieszkównie.

Przedmiot ten znany jest także jako Psałterz Egberta. Zaczął powstawać najprawdopodobniej w latach 977-993, czyli podczas pontyfikatu swojego pierwszego właściciela, arcybiskupa trewirskiego Egberta ${ }^{18}$. Początkowo na zbiór składały się tylko psalmy. Tekst spisywany był przez Ruodprehta, który jest bohaterem pierwszej miniatury znajdującej się w rękopisie ${ }^{19}$.

W momencie, gdy Psałterz trafił w ręce Gertrudy (w 1043 r.), składał się z czterech zasadniczych części: Psatterz Egberta, Litania, Wyznania i Ordynacja. Modlitwy i cztery z pięciu miniatur Gertrudy umieszczone zostały na dodatkowych składkach (tzw. Folia Gertrudiana), o które poszerzono zbiór $^{20}$. Gertruda zapisywała także wolne miejsca w pozostałych częściach ${ }^{21}$.

\footnotetext{
13 F. Sielicki, Powieść..., s. 159.

14 S. Kętrzyński, Gertruda (ok. 1025-1108)..., s. 406.

J. Strzelczyk, Pióro w wątlych dłoniach..., s. 113.

16 Ibidem, s. 113-114.

17 F. Sielicki, Powieść..., s. 221.

18 S. Kętrzyński, Gertruda (ok. 1025-1108)..., s. 406.

19 B. Kürbis, Modlitwy księżnej Gertrudy z Psalterium Egberti. Przyczynek do dziejów kultury dworu panujacego w Polsce i na Rusi, „Sprawozdania” 1979, nr 96, s. 3-11.

20 J. Strzelczyk, Pióro w wattych dłoniach..., s. 119.

21 A. Andrzejuk, Gertruda Mieszkówna..., s. 151.
} 
Na manuskrypt Gertrudy składa się 6 części: Kalendarium, Modlitwy oraz pierwsza z miniatur, Interpolacja Filipa $z$ Turris, trzy kolejne miniatury, Prognostyki: księżycowy i pogodowy oraz Modlitwy Gertrudy ${ }^{22}$. Tekstów, których autorstwo przypisuje się Gertrudzie jest 95. Są one ze sobą ściśle związane, zarówno pod względem tematycznym, jak i chronologicznym. Przedmiotem sporu badaczy jest moment, w którym księżna zaczęła tworzyć teksty. Według Małgorzaty H. Malewicz, pierwsze zapisane modlitwy mogły składać się na te, które Gertruda pamiętała z pobytu w klasztorze. Natomiast Teresa Michałowska twierdzi, że swój zbiór księżna zaczęła tworzyć podczas pobytu w Saksonii ${ }^{23}$. Bardziej prawdopodobna jednak wydaje się teza druga, zwłaszcza, jeżeli weźmie się po uwagę wspomnianą wyżej chronologię.

Obecnie Kodeks Gertrudy znajduje się w Museo Archeologico Nazionale w Cividale, opatrzony sygnaturą Cod. Cap. CXXXVI Inv. 1545²4.

Niemal we wszystkich tekstach ujawnia się osobowość Gertrudy. Księżna wyraża się bezpośrednio, używając zwrotów takich, jak: „ja Gertruda”, „mnie” itd. W tym zakresie nie ulega wątpliwości kwestia autorstwa. Brak oficjalnych dedykacji. Nie pojawiają się imiona bliskich Gertrudy: Mieszka II, Rychezy czy nawet Izjasława. W ostatnim przypadku, nie został zaznaczony także fakt jego śmierci, chociaż zastanawiający jest jednak „brak jednej składki w miejscu, w którym [...] mógł być [...] odnotowany”25. Wyjątek stanowią modlitwy poświęcone Piotrowi, którego imię pojawia się nader często.

Nie można dostrzec żadnych odniesień bezpośrednich do bieżących wydarzeń towarzyszących powstawaniu Modlitewnika ${ }^{26}$. Zestawiając jednak burzliwe losy Gertrudy z tematyką modlitw, można dostrzec pewną analogię. Teksty o konkretnej tematyce (błagalne, modlitwy za zmarłych) splatają się z wydarzeniami, w które uwikłana była księżna. Dobrym przykładem jest tu wyprawa Jaropełka-Piotra do Rzymu, co do której w Modlitewniku można odnaleźć tekst następującej treści:

Odwróć serce króla od nienawiści, od niechęci i gniewu,/ a zwróć do ku łagodności i pokojowi oraz dobroci,/ aby stał się łagodny i miłosierny oraz przychylny słudze Twojemu N./ Panie Jezu Chryste, broń go swą pomocą,/ aby ani odwieczny wróg, ani zły człowiek,/ ani jego wrogowie nie przemogli go./ Daj mu, Panie, prawdziwą pokorę i prawdziwą miłość./ Utwierdź w nim

\footnotetext{
Ibidem, s. 144.

Ibidem, s. 152.

J. Strzelczyk, Pióro w wątlych dłoniach..., s. 119.

Ibidem, s. 34.

6 Ibidem, s. 120.
} 
prawdę Bożą,/ aby nietknięty i nienaruszony/ mógł pokonać niegodziwości wszystkich swoich wrogów./ Nie wydaj go, Panie, w ręce jego nieprzyjaciół,/ lecz uczyń go mężnym i stałym przeciwko wszystkim jego wrogom, widzialnym i niewidzialnym,/ aby uzbrojony Twoją opieką zasłużył sobie służyć Ci jako zbawiony./ Wszechmogący Ojcze,/ abyś króla i całe księstwo dla sługi Twego [...] łagodnym i miłosiernym, i łaskawym uczynić raczył/ błagam Cię, wysłuchaj mnie!/ Abyś ich gniew i niechęć wobec sługi Twojego, zamienić na łagodność raczył/ błagam Cię!/ Abyś niegodziwość i zawiść wszystkich jego nieprzyjaciół pognębić raczył/ błagam Cię, wysłuchaj mnie!/ Abyś wszystkich, którzy chcą mu się sprzeciwiać prawicą swojej mocy pognębić raczył/ błagam Cię!/ Abyś wszystko, cokolwiek nieprzyjaciele podstępnymi spiskami przeciwko niemu knują, w niwecz obrócić raczył/ błagam Cię, wysłuchaj mnie!/ Abyś sługę Twojego od wszystkiego, co jest Ci przeciwne, odwrócić raczył/ błagam Cię, wysłuchaj mnie!/ Abyś prawdziwą i braterską miłość oraz dobrą zgodę umocnić w nim raczył/ błagam Cię, wysłuchaj mnie!/ Abyś go od wszelkich zasadzek nieprzyjaciół jego, widzialnych i niewidzialnych, łaskawie wyzwolić raczył./ Abyś mu łaski swojej oraz dobrego końca i radości wiecznej, zgodził się udzielić./ błagam Cię, wysłuchaj!/ Wyślij Panie z nim swojego świętego anioła,/ aby go strzegł i bronił,/ od wszelkiego niebezpieczeństwa duszy i ciała go zachował,/ a jego stopy zawsze skierowywał na drogę pokoju i zbawienia,/ aby przebywał z nami z radością i pokojem/ a gdziekolwiek się uda, niech będzie miał dany szczęśliwy do nas powrót./ Boże Abrahama, bądź mu bronią cnoty! AMEN/ Boże Izaaka, bądź mu hełmem zbawienia!/ Boże Jakuba, bądź mu tarczą niezwyciężoną,/ przeciwko wszystkim nieprzyjaciołom jego widzialnym i niewidzialnym!/ AMEN ${ }^{27}$.

Modlitewnik Gertrudy jest specyficznym nośnikiem informacji o autorce. Starannie dobrane słowa, niebanalne zwroty i głębokie przemyślenia są dowodem inteligencji samej autorki oraz wszechstronnego jej wykształcenia. Każda modlitwa jest dobrze przemyślana, logiczna i spójna. Niesie ładunek emocjonalny, odpowiadający stanowi ducha autorki w momencie spisywania: „Miejscami pismo jest niestaranne, jakby nerwowe, zdaje się zdradzać silne napięcie emocjonalne. [...] Te teksty mają znamię osobiste, sprawiają wrażenie brulionowych notatek, czegoś, co było pisane z potrzeby chwili"28. Autorka odznacza się dokładną znajomością Pisma Świętego, porządku liturgii oraz świętych. Można zaryzykować twierdzenie, że biorąc pod uwagę

27 A. Andrzejuk, Gertruda Mieszkówna..., s. 193-194.

28 http://www.tygodnik.com.pl/numer/276931/michalowska.html [dostęp: 30.01.2015]. 
jej współczesne otoczenie, wybija się ponad kanon poglądów o kobiecie jej czasów. Zadziwiające, jak odmiennie w relacji ze stereotypowym wizerunkiem kobiety w średniowieczu prezentuje się Gertruda pod względem wykształcenia, erudycji, wiedzy, a szczególnie umysłowości. Co więcej, księżna odznaczała się niebywałym zmysłem politycznym. Niektóre jej modlitwy przypominają coś na kształt zeznania, niemal ascetycznego wyznania grzechów, w którym autorka podkreśla swoje zaangażowanie w działania innych ludzi, nie zawsze prowadzące ku dobremu. Niemniej jednak ostatecznie nie można uznać Kodeksu za autobiografię. Brak zasadniczych cech, które dominują w tego typu tekstach. Bez wątpienia jest dzieło Gertrudy jedynym w swoim rodzaju lustrem, odbijającym niezwykłą kobietę swojej epoki. Czy było więcej takich kobiet? Zapewne. Nie zostawiły po sobie jednak spuścizny, która byłaby świadectwem ich dokonań i umiejętności.

\section{Bibliografia}

\section{Źródła}

SIELICKI F., Powieść lat minionych, Wrocław-Warszawa-Kraków 1999.

\section{Opracowania}

ANDRZEJUK A., Gertruda Mieszkówna i jej modlitewnik, Warszawa 2006.

BALZER O., Genealogia Piastów, Kraków 1895.

http://www.tygodnik.com.pl/numer/276931/michalowska.html [dostęp: 30.01.2015]. KĘTRZYŃSKI S., Gertruda (ok. 1025-1108), w. księżna kijowska, [w:] Polski słownik biograficzny, t. 7, red. W. Konopczyński, Kraków 1949-1958, s. 405-406.

KÜRBIS B., Modlitwy księżnej Gertrudy z Psalterium Egberti. Przyczynek do dziejów kultury dworu panującego w Polsce i na Rusi, „Sprawozdania”, nr 96, 1979, s. 3-11.

STRZELCZYK J., Pióro $w$ wątlych dłoniach: o twórczości kobiet $w$ dawnych wiekach. Rozkwit (od Murasaki Shikibu do Małgorzaty Poerte), Warszawa 2009. 
Karolina Sztachańska

\section{Aneks}
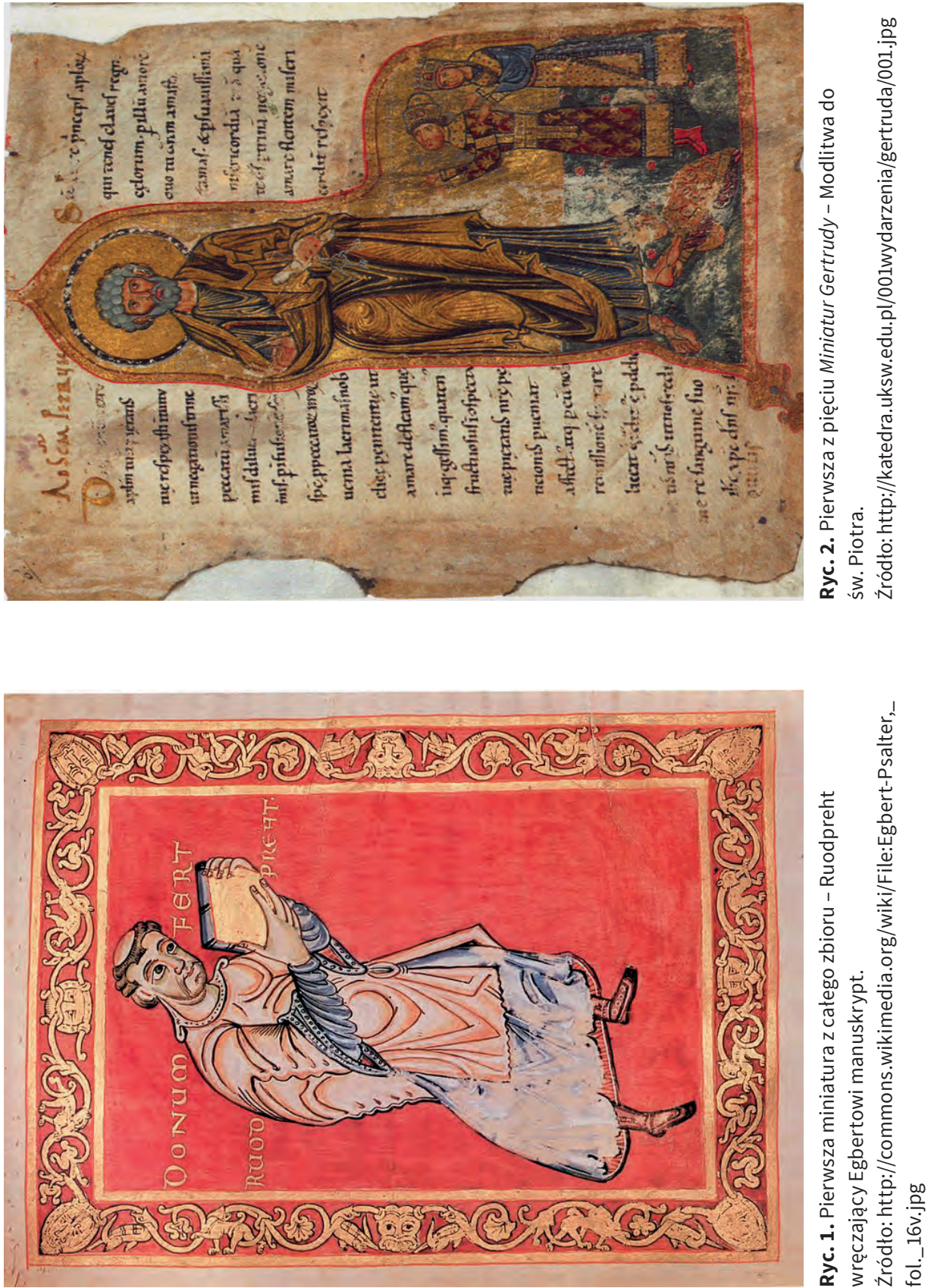
Kodeks Gertrudy, przypadkowa autobiografia księżnej?
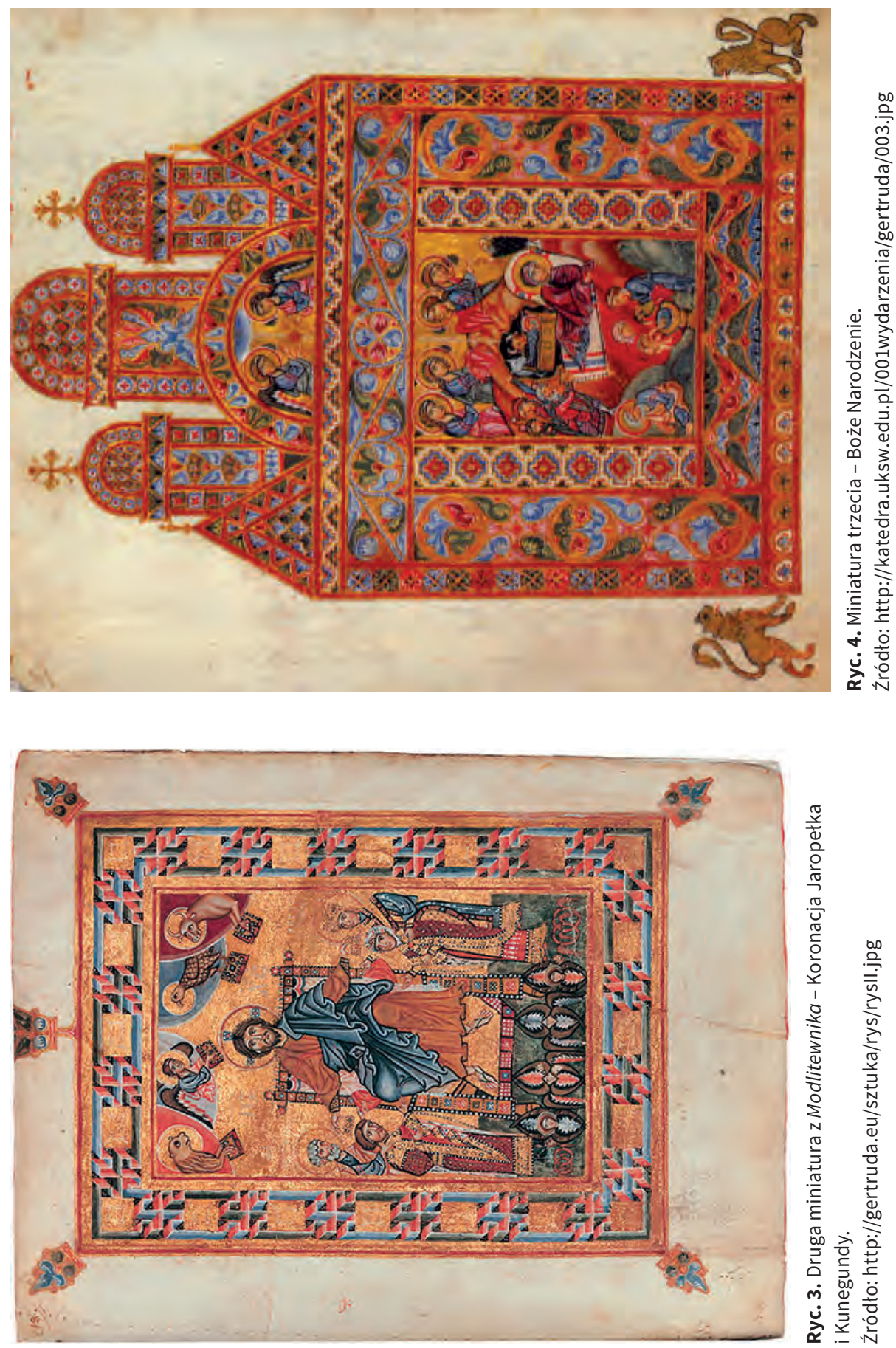
Karolina Sztachańska
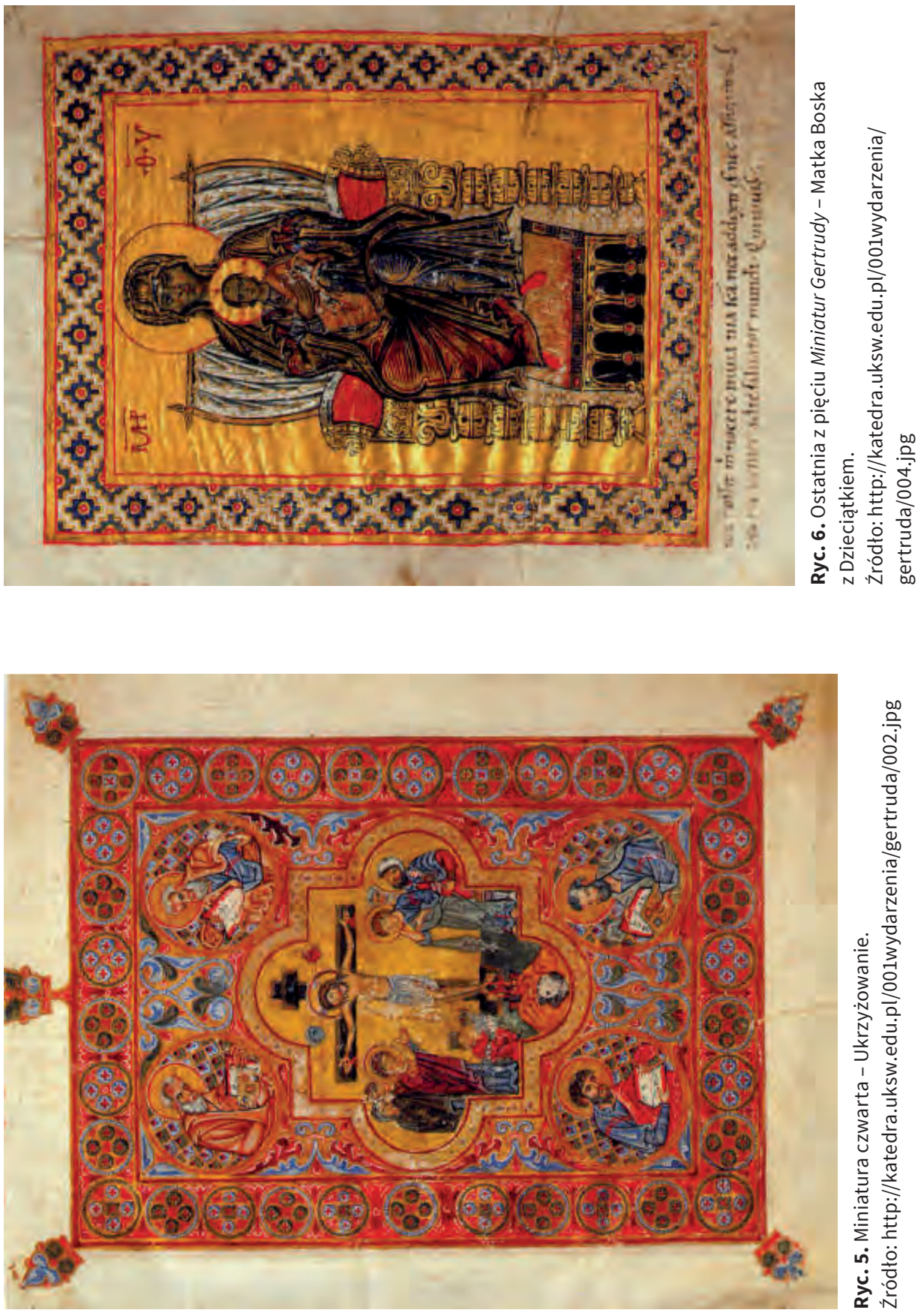